\title{
Neonatal Changes in Plasma Erythropoietin in Fast Growing Pigs
}

The rapid growth rate of piglets puts a heavy demand on their hematopoietic system. Iron is a rate-limiting factor in erythropoiesis in neonatal pigs unless they are supplemented with iron. Pigs recieving no extra iron soon develop anemia, and values of hemoglobin below $40 \mathrm{~g} / 1$ are often being encountered within 2 weeks of birth (Holter et al. 1991). Piglets treated with iron at birth, on the other hand, exhibit only a temporary and minor reduction in hemoglobin concentration (Bollwahn et al. 1971, Holter et al. 1991). Erythropoietic activity is controlled by erythropoietin, a protein hormone which is mainly produced in the kidneys. Hypoxia is generally supposed to be the fundamental stimulus to trigger erythropoietin production. Contradictory results exist as to whether this is the case in the neonatal period. In accordance with the hypoxia theory, Halvorsen \& Finne (1968) reported that the change from the placenta to the lungs as the respiratory organ, is associated with a reduction in the plasma levels of erythropoietin in man. Meberg et al. (1980), on the other hand, found high plasma concentrations in neonatal mice in which the hemoglobin concentration was only slightly reduced. Further, Håga et al. (1983) found a positive and significant correlation between plasma erythropoietin and weight gain in premature babies, but no correlation between erythropoietin and hemoglobin. These observations led them to propose that other factors, such as weight gain per se, is of importance for the control of erythropoietin production at an early stage of life. In accordance with the weight gain theory, Holter (1987) observed a moderate increase in plasma erythropoietin concentrations in some baby rabbits during periods of rapid growth and improved $\mathrm{O}_{2}$ supply to the tissues.

The piglets in a litter of Norwegian Landrace were divided into 2 groups, 7 piglets in each group. The piglets in one group (average birth weight $1.44 \mathrm{~kg}$ ) were injected with 180 mg iron at days 1 and 14 whereas the piglets in the other group(average birth weight 1.42 $\mathrm{kg}$ ) were given $180 \mathrm{mg}$ only at day 14 . The iron injections were given just after blood sampling. The piglets were kept in a pen together with the mother, and they had access to a milk substitute and water from day 1 to day 11, and pelleted food for piglets and water from day 11 onwards. Blood was drawn from the external jugular vein at set days, and plasma erythropoietin was estimated by a monoclonal enzymimmunoassay (ELISA), using human erythropoietin antibodies (Epo-Elisa Test medac, Medac, Hamburg). Since porcine erythropoietin is unavailable, the degree of crossreaction between this antigen and the erythropoietin antibodies used was not estimated, and only relative values for the hormone can be given. The coefficient of inter-assay variation of the 
method was 10 percent. Hemoglobin concentration was estimated in a Cell-Dyn 400 and New methylene blue was used for the staining of reticulocytes.

In Fig. $1 \& 2$ the values for plasmaerythropoietin for 1 piglet in each group are given, the curves being representative for their specific groups (Fig. 1 \& 2). In all piglets, plasma erythropoietin was low, but detectable, at birth, whereafter it increased rapidly during the first day of life. The mean erythropoietin activity $24 \mathrm{~h}$ after birth was 48 $\pm 40 \mathrm{mlU} / \mathrm{ml}$. In the group given iron at day
1 , erythropoietin decreased rapidly during the next 3 days and remained low from about 10 days of birth and onwards (Fig. 1). Average erythropoietin activity in this group at day 14 was $5.8 \pm 1.7 \mathrm{mlU} / \mathrm{ml}$. In the piglets which did not recieve iron at day 1 , a second increase in erythropoietin was observed from day 8 to day 14, a period in which the anemia became increasingly worse (Fig. 2). In this group, erythropoietin activity at day 14 was $72.1 \pm 67.1 \mathrm{mlU} / \mathrm{ml}$. Iron treatment at day 14 improved hemoglobin values, and erythropoietin promtly dropped to the level

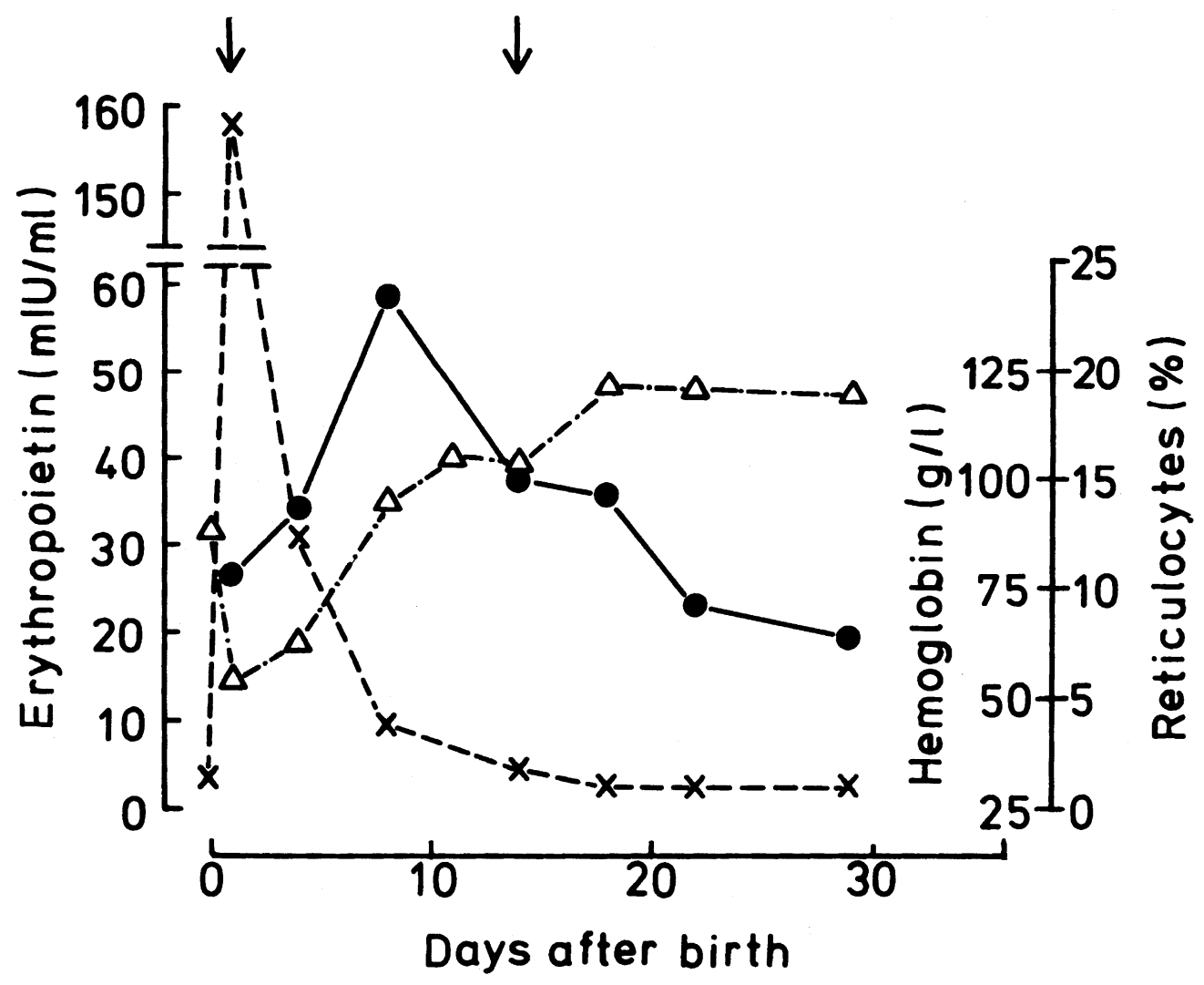

Figure 1. Neonatal changes in plasma erythropoietin, hemoglobin concentration and reticulocytes in a piglet given $180 \mathrm{mg}$ of iron subcutaneously both 1 day and 14 days after birth. Iron was given as indicated by arrows. $X=$ erythropoietin. $\Delta=$ hemoglobin. $\bullet=$ reticulocytes. 


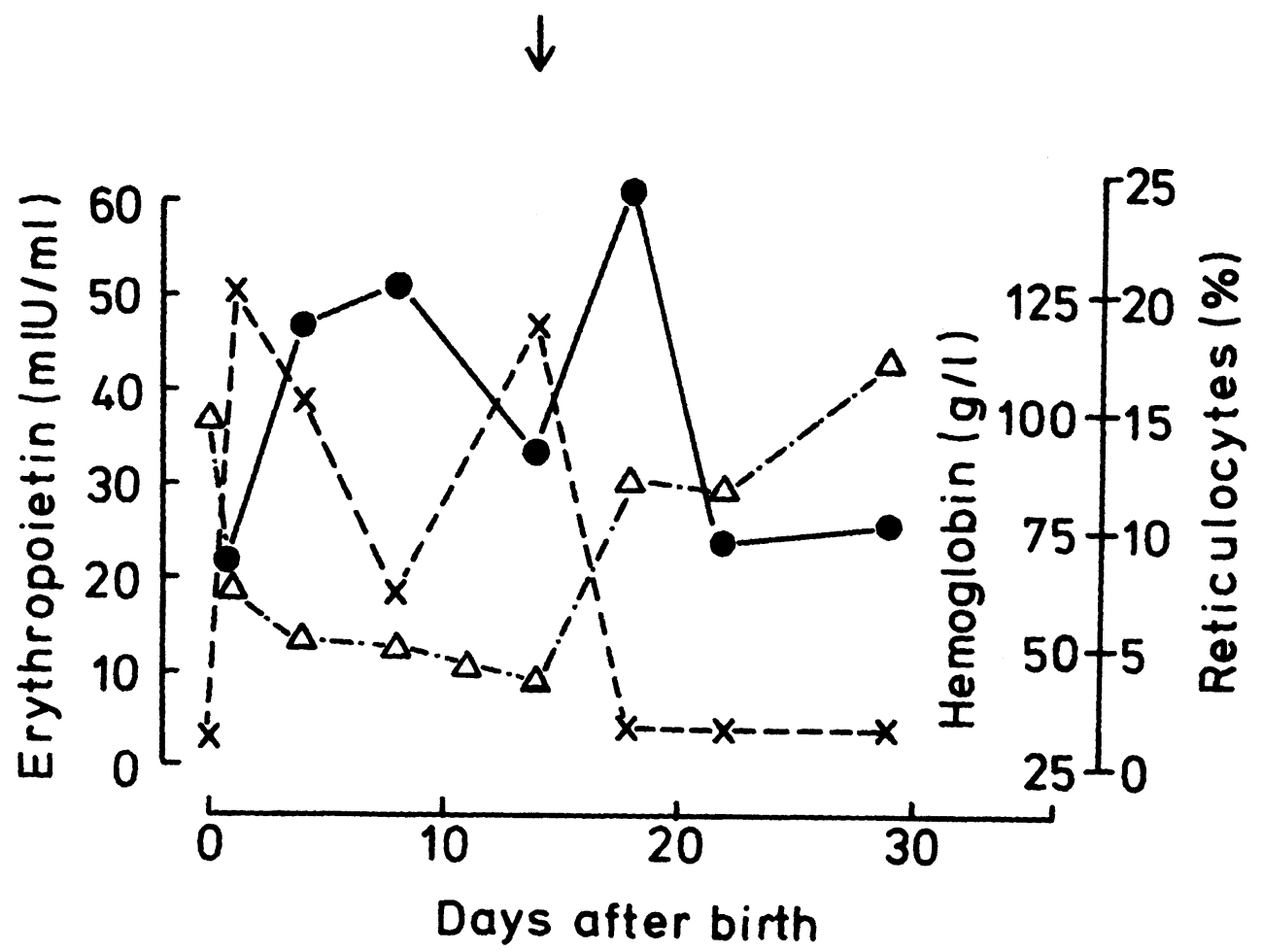

Figure 2. Neonatal changes in plasma erythropoietin, hemoglobin concentration and reticulocytes in a piglet given $180 \mathrm{mg}$ of iron subcutaneously 14 days after birth. Iron was given as indicated by arrow. $X=$ erythropoietin. $\Delta=$ hemoglobin. $\bullet=$ reticulocytes.

observed at birth. In both groups, the profile of the reticulocyte curve during the first 2 weeks was similar to that of erythropoietin, when a delay of 2-3 days for the reticulocyte values is included.

In the piglets which were not treated at day 1 , the changes in erythropoietin from day 8 to day 14 , and from day 14 to day 22 , are probably due to changes in hemoglobin, and thus changes in the tissue supply of $\mathrm{O}_{2}$. Weight gain, expressed as percentage change in body weight per unit time, has probably not influenced erythropoietin values significantly in the present experiments, since it is fairly constant in the neonatal period (Fram- stad \& Sjaastad 1989).

The large increase in plasma erythropoietin the first day of life, and the subsequent rapid drop the next days is unexpected and not easily explainable. For the piglets given iron at day 1 , it might be argued that these changes in plasma erythropoietin are due to the observed changes in hemoglobin. However, the decrease in erythropoietin from day 1 to day 8 in the piglets not given iron at birth, cannot be explained in terms of changes in hemoglobin. Hypothetically, this decrease in erythropoietin could be related to the increase in $\mathrm{Po}_{2}$ occurring upon birth.

The dramatic changes in erythropoietin 
activity in the early neonatal period in pigs is an interesting physiological feature. The reasons for these changes are at present unclear, and will be object of studies in progress.

\section{$\emptyset$. V. Sjaastad, T. Framstad and A. K. Blom.}

Department of Physiology and Nutrition, and Department of Reproduction and Forensic Medicine, Norwegian College of Veterinary Medicine, $P$. O. Box 8146, N-0033 Oslo 1, Norway.

\section{References}

Bollwahn W, Vaske T, Rojas M, Wenz I: Die Hämatopoese neugeborener Ferkel und ihre Beeinflussung durch Eisendextran $\left(\right.$ Myofer $\left.^{\circledR}\right)$. (Influence of irondextran (Myofer ${ }^{\circledR}$ ) on hematopoiesis in newborn pigs). Das Blaue Hefte 1971, 45, 171-181.

Framstad T, Sjaastad $\emptyset$ : Jernmangelanemi hos smågris. En kollision mellom fysiologi og produksjonsmiljø. (Anemia in piglets due to iron deficiency. Conflict between physiology and production system). Norsk Vet. Tidsskr. 1989, 101, 925-930.

Halvorsen S, Finne $R H$ : Erythropoietin production in the human fetus and newborn. Ann. NY. Acad. Sci. 1968, 149, 576-577.

Holter PH, Framstad T, Aulie A, Refsum $H E$, Sjaastad $\emptyset V$ : Effect of iron treatment on erythrocyte parameters in postnatal anemia of the pig. Pediatr. Hematol. and Oncol 1991, 8, 1-11.

Holter P H, Sanengen T, Halvorsen S, Refsum H E: Regulation of erythropoiesis in suckling rabbits with and without postnatal anemia: Partial suppression of production/release of erythropoiesis stimulating factor(s) by iron supplements, Pediatr. Res. 1987, 21, 1-4.

Hågå P, Meberg A, Halvorsen S: Plasma erythropoietin concentrations during the early anemia of prematurity, Acta Paediatr. Scand. 1983, 72, 827-831.

Meberg A, Hågå P, Johansen M: Plasma erythropoietin levels in mice during the growt period. Br. J. Haematol. 1980, 45, 569-572.

(Accepted May 22, 1992).

Reprints may be requested from: $\emptyset$. V. Sjaastad, Department of Physiology and Nutrition, Norwegian College of Veterinary Medicine, P. O. Box 8146, N - 0033 Oslo 1, Norway. 